\title{
Cerebellar Stroke in Young Female Due to Lutembacher Syndrome
}

\author{
Adnan Bashir Bhatti ${ }^{1}$, Farhan $\mathrm{Ali}^{2}$, Siddique Akbar Satti ${ }^{3}$, Shuja Ur Rehman ${ }^{4}$, \\ Muhammad Usman', Maham Abbasi ${ }^{6}$ \\ ${ }^{1}$ Department of Medicine, Capital Development Authority (CDA) Hospital, Islamabad, Pakistan \\ ${ }^{2}$ Department of Medicine, Capital Development Authority (CDA) Hospital, Islamabad, Pakistan \\ ${ }^{3}$ Department of Medicine, Capital Development Authority (CDA) Hospital, Islamabad, Pakistan \\ ${ }^{4}$ Department of Medicine, Capital Development Authority (CDA) Hospital, Islamabad, Pakistan \\ ${ }^{5}$ Department of Medicine, Jinnah Hospital Lahore (JHL)/ Allama Iqbal Medical College (AIMC), Lahore, Pakistan \\ ${ }^{6}$ Department of Medicine, Jinnah Hospital Lahore (JHL)/ Allama Iqbal Medical College (AIMC), Lahore, Pakistan \\ Abstract: Lutembacher syndrome is a combination of mitral stenosis and a left-to-right shunt at the atrial level \\ due to atrial septal defect (ASD) and both of these defects can either be congenital or acquired. We report a case \\ of a young female who presented with shortness of breath, palpitations, scanning speech and right sided \\ weakness. Her clinical and laboratory features showed a case of right sided cerebellar infarct secondary to \\ Lutembacher syndrome.
}

\section{INTRODUCTION}

Lutembacher's syndrome is an extremely rare form of congenital heart disease. It was first described by a French cardiologist Lutembacher in $1916^{\mathbf{1}}$. It is a combination of mitral stenosis and a left-to-right shunt at the level of atria due to an atrial septal defect (ASD) [ostium secundum variety] ${ }^{2}$.

The gender predominance is inclined towards females. It has an incidence rate of $0.001 / 1,000,000$. In a US study, this syndrome was detected in 5 out of 25,000 autopsies ${ }^{2,3}$.

Most people remain asymptomatic, but when symptoms appear, they are mainly of atrial septal defect and mitral stenosis. Symptoms of ASD depend on the size of the defect. If the defect is large, pulmonary congestion happens later during the course of disease. But, if the patient has a small ASD with mitral stenosis, pulmonary congestion and related symptoms appear early².

In our case, patient presented with complication of mitral stenosis i.e. thromboembolic stroke in cerebellar region.

\section{CASE}

A 21 year old female presented to Capital Hospital Islamabad with complaints of headache, disorientation, shortness of breath, palpitation and right sided weakness. She also complained of vomiting during these episodes. Patient was unmarried with low socioeconomic back ground. She had past history of rheumatic fever three years back and was started on benzithine penicillin on monthly basis.

On examination, she appeared thin and malnourished. She had poor oral hygiene and enlarged tonsils. Irregularly irregular pulse and pulses deficit was 18. Blood pressure was 110/70 and respiratory rate was 16/min.

She had right sided weakness, which presented as less muscle power on the right side of her body as compared to the left. Power in right upper and lower limb was $4 / 5$ and left upper and lower limb was 5/5. Plantar reflex on right side was equivocal and down going on left side. There was no wasting, fasciculation and tone and reflexes were normal. However, waddling gait, scanning speech, intention tremor, rebound phenomena, past pointing and Romberg signs were positive (features of cerebellar lesion).

Cardiac examination revealed fixed splitting of S2 and mid-diastolic murmur at mitral area. Peripheral edema and JVP were not raised. Other systems were unremarkable.

\footnotetext{
${ }^{1}$ Corresponding Author: dr.adnanbashir@gmail.com
} 


\section{American Research Journal of Medicine And Surgery, Volume 1, Issue 2, 2015 ISSN 2379-8955}

Electrocardiogram revealed irregularly irregular heart rate of 100/min and absent p wave. CT scan of the brain showed multiple left sided supra and infra-tentorial infarcts (infarcts in right cerebellar region). Echo was performed that showed reduced mitral valve area, enlarged left atrium, left to right shunt and small hole between atrial septum. Blood complete picture and serum ferritin showed iron deficiency anemia. Blood chemistry and ultrasound were unremarkable.

A diagnosis of right sided ischemic cerebellar stroke due to atrial fibrillation was made. Underlying etiology was Lutembacher's syndrome.

Patient was supportively treated for the cerebellar stoke and nutritional deficiency anemia, she was given Aspirin $300 \mathrm{mg}$ once a day, Tab. Digoxin $0.25 \mathrm{mg}$ once a day.

After six month, she underwent mitral valve replacement and atrial septum repair. She recovered successfully and was put on lifelong warfarin therapy

\section{DISCUSSION}

The definition of Lutembacher syndrome has undergone many changes over the past decades. The earliest mention of Lutembecker's syndrome in medical literature comes for letter written by anatomist Johann Friedrich Meckel to Albrecht von Haller in $1750{ }^{1}$. Currently, any combination of ASD (congenital or iatrogenic) and mitral stenosis (congenital or acquired) is labeled as Lutembacher syndrome.

In our case, the patient had congenital ASD and acquired mitral stenosis following rheumatic fever.

Major symptoms of Lutembacher's syndrome, which are due to atrial septal defect and mitral stenosis, can range from heart failure to pulmonary congestion. Atrial arrhythmias or atrial fibrillation are the main complication that follow the dilatation of atrium ${ }^{4}$.

According to some authorities, the risk of stroke is increased fivefold in individuals with $\mathrm{AF}$ and this risk increases to seventeen folds in patients with atrial fibrillation with congenital heart disease $(\mathrm{CHD})^{5}$. In atrial fibrillation, irregular atrial contraction can result in stagnation of blood in the left atrium or left atrial appendage, which can result in thrombus formation. An embolus proceeds through smaller and smaller arteries until it plugs one of them and prevents blood and oxygen perfusion to the area distal of blockade. Eventually, it results in end-organ damage ${ }^{6}$.

In our case, the patient presented with ischemic cerebellar stroke due to atrial fibrillation, which is complication of lutembecker syndrome.In literature very few cases have been reported of lutembecker syndrome. Our case is extremely rare because cerebellar stroke due to lutembecker syndrome is not mentioned in the literature to the best of our knowledge.

Lutembacher's syndrome is diagnosed primarily by physical examinations for heart sounds, electrocardiograms, chest radiogram, transthoracic or transesophageal echocardiography, color flow mapping, and Doppler imaging. Use of these tests can help differentiate other possible conditions such as mitral regurgitation, Ebstein disease, ventricular septal defect $(\mathrm{VSD})^{7-10}$.

The different treatment options are available for lutembacker syndrome such as percutaneoustrans catheter therapy for MS and percutaneous device closure of $\mathrm{ASD}^{11,12}$. One case report showed the beneficial effects of percutaneous balloon valvuloplasty for MS and Amplatzer septal occluder for closure of the $\mathrm{ASD}^{13}$. Another study showed that Percutaneous Leaflet Plication (Edge-to-Edge Leaflet Repair) improves the survival rate ${ }^{14}$. Complicated cases may even need open heart surgery.

In our case open heart surgery was done, ASD was closed directly and mitral valve was replaced with a metallic valve

\section{CONCLUSION}

Stroke in young patient indicates that there is some cardiac problem. Clinician should be aware of Lutembacher syndrome and its rare presentations. Early diagnosis can prevent major complications and increase the survival rate. 


\section{REFERENCES}

[1] Wiedemann HR. Earliest description by Johann Friedrich Meckel, Senior (1750) of what is known today as Lutembacher syndrome (1916). Am J Med Genet. Oct 15 1994;53(1):59-64.

[2] Kulkarni, Sandhya; Amit K. Sakaria; Sanket K. Mahajan; Kuldeep B. Shah "Lutembacher's syndrome". Journal of Cardiovascular Disease Research (2012). 3 (2): 179-181.

[3] Quash JA, Davia JE, de Castro CM, Bowen TE, Green DC. Echocardiography in Lutembacher'ssyndrome.Chest. Nov 1977;72(5):676-8.

[4] Kulkarni, Sandhya; Amit K. Sakaria; Sanket K. Mahajan; Kuldeep B. Shah (2012). "Lutembacher'ssyndrome".Journal of Cardiovascular Disease Research 3 (2): 179-181.

[5] Wolf PA, Dawber TR, Thomas HE Jr, Kannel WB.Epidemiologic assessment of chronic atrial fibrillation and risk of stroke: the Framingham study.Neurology. 1978 Oct;28(10):973-7.

[6] Santiago D1, Warshofsky M, Li Mandri G, et al. Left atrial appendage function and thrombus formation in atrial fibrillationflutter: a transesophageal echocardiographic study.J Am CollCardiol. 1994 Jul;24(1):159-64.

[7] Ansari A, Maron BJ. Lutembacher's syndrome. Tex Heart Inst J. 1997;24(3):230-1.

[8] Crawford MH. Iatrogenic Lutembacher's syndrome revisited. Circulation. Apr 1990;81(4):1422-4.

[9] Horstkotte D, Niehues R, Strauer BE. Pathomorphological aspects, aetiology and natural history of acquired mitral valve stenosis. Eur Heart J. Jul 1991;12Suppl B:55-60 